\title{
Modes of housing production in developing countries: the contemporary role of land, labour, and capital in Lagos, Nigeria
}

\author{
Corresponding Author \\ Title, First Name, Surname: Mr. Muyiwa Agunbiade \\ Institution: University of Melbourne \\ Email: m.agunbiade@pgrad.unimelb.edu.au \\ Co-author \\ Title, First Name, Surname: Prof. Abbas Rajabifard \\ Institution: University of Melbourne \\ Email: abbas.r@unimelb.edu.au \\ Co-author \\ Title, First Name, Surname: Dr. Rohan Bennett \\ Institution: The University of Twente \\ Email: bennett@itc.nl
}

\begin{abstract}
The strategies of participants in housing production, in developing countries, are diverse and not fully understood. Governments in most developing countries have not been able to, sufficiently, explore how the production factors: land, labour and capital, impact on housing production. As a result, many policies formulated by governments aimed at stimulating housing production are found to result in unintended outcomes: they do not always align with the way housing is actually created. This study uses the production factors to assess how motivations are shaped and different modes of housing production result. The aim is to gain an improved understanding of how housing developers, builders and government, impact modes of production. The method includes synthesis of past studies on factors of housing production in Lagos. In parallel, it also involves visits and interviews with some selected developers and agencies to allow a deeper engagement with their activities. This is in addition to direct observation and interviews undertaken through purposeful selection of some autonomous (on-site) builders. As an exploratory study, it observes that a better approach to land supply is significantly beneficial in shaping the modes and capacity of housing. The study helps understand the strategies of participants in housing production in developing countries, especially in Lagos. It recommends that efficient land supply to the autonomous on-site builders should be a focus for policy makers. This will contribute to the production of more housing thereby facilitating an improved production of present and future housing needs of the population.
\end{abstract}

Keywords: land, labour, capital, developers, profit, owner occupier, housing production 


\section{Introduction}

Neither public-sector efforts (provider paradigm) nor the favoured private sector efforts (enabling paradigm) have had, significant positive, impacts on urban dwellers' shelter provision in most developing countries. The public sector programmes have often been limited, expensive and have required large subsidies, thus making long-term replication difficult if at all possible (UNCHS, 1991). The implementation strategies are also observed to be administratively intensive and slow.

Conversely, the enabling paradigm, which emphases private market as the major source of housing production, is considered misplaced. Keivani and Werna (2001) argue that the private sector requires support, but, that it should not necessarily be the focus for the production of housing in the developing countries.

Consequently, the reform of the housing sector has been a recurrent issue of policy debate in most national jurisdictions. This debate is structured particularly in the context of rapid urbanisation, demographic pressure, slum formation and increasing demand for housing, land and infrastructure' (UN-HABITAT, 2010). To get the reforms right means getting underlying housing delivery systems to work better. Achieving this has been a considerable challenge.

It is thus important to examine the predominant processes and modes of housing supply with respect to strengths, weaknesses, and critical constraints (UN-HABITAT, 2010). The examination of existing literature in developing countries suggests that the government has not fully understood the processes of housing production, and the utilisation of the basic production factors (Hamdi, 1995; Keivani and Wernab, 2001; Ogu and Ogbuozobe, 2001; UN-HABITAT, 2010; World Bank, 1988). In this regard, what drives or motivates the participants in housing production are not fully explored. Consequently, several policies formulated by the respective governments aimed at stimulating the production of housing have resulted in unintended outcomes (UNCHS, 1990).

To logically explore the gaps between policies and outcomes requires an analysis of the interplay of the production factors in mediating housing construction. This broad examination needs to be situated within the provider and enabling paradigm described above, and also the profit-motive concept. This is necessary in order to understand governments' strategies to facilitate housing production as well as developers'/builders' strategies to respond to these. Motive, as observed by Wood and Ong (2010), is usually driven by consumption and investment demand while utilising the factors of production. From the neo-liberalist perspective of private investment, the motivations to engage in housing production usually involve profit. Conversely, motivations could be substantially geared towards satisfying one of the basic necessities of life, which is shelter, as it is for most autonomous ${ }^{1}$ housing production (Agbola, 1988; Omirin and Antwi, 2004).

Past studies concentrated on the challenges of adopting indigenous labour expertise in housing production (Aina, 1988); the cost of building materials (Ikejiofor, 1997); building approval processes (Olokesusi and Okufolure, 2001); the system for allocating urban land and development rights (Egbu et al., 2008); general overviews of housing production problems (Onibokun, 1983, 2003); and technology of building construction (Adeola, 2006, 2008; Olumide and Adelore, 2005). While all these are valuable contributions, there was less emphasis on how these issues could be integrated to assist the understanding of

\footnotetext{
${ }^{1}$ These are individual developers or builders motivated to develop dwellings in the form of both asset formation and housing services for their exclusive use.
} 
drivers for housing development and how individuals pursue their strategies. An analysis of the range of proportional contributions of production factors in housing production is thus necessary.

The overarching aim of this paper is to contribute to developing better policy options that will enhance housing production at scale. This will be done by developing a model for understanding the different types of builders in the utilisation of production factors (land, labour and capital) and outlining how this potentially impact policy options for government. To achieve this will involve exploring the willingness and the motivation of developers or builders to produce housing having regard to the anticipated benefit. The benefit is assessed based on the expectation of meeting the basic shelter needs and/or profit accruable through investment in housing production.

The discussion starts with a short description of provider and enabling paradigms in parallel with the pluralistic approach. This provides a context of governments' past, present and future (intended and reactive) policies. The overarching research method is then outlined. The research design involves the use of a case study approach, and the situation in Lagos is utilised. A brief description and characteristic of Lagos is thus offered to provide an overview of the case study. To fully understand how housing production processes are mediated by the production factors, attention is focused on the different production modes. In this regard, housing production processes are structured along the motives for construction. Through this analysis, the later parts classify housing production along two clusters: organised and autonomous productions. It discusses the profit-motives context of each of the production clusters and the corresponding developers' drivers for housing production. The final parts contain discussions on how policies could be developed around these production clusters to facilitate housing production at scale in Lagos. It is anticipated that this has prospect for application in other national context with similar circumstances.

\section{Housing Production Paradigm}

Researchers have adopted different approaches to classify housing production processes using different contexts. Hamdi (1995) identified two paradigms in terms of approaches to housing delivery that impact motivation for housing production. These are the provider and the enabling (supporter) paradigms. These depend on the extent and nature of public involvement in housing delivery, as well as the capacity of household in terms of level of household income. The provider paradigm advocates that government essentially should control the production of houses in order to reduce housing shortfall and improve the quality of housing. Conversely, the enabling paradigm does not favour government production of houses, but favours as an alternative, the support of householders, smallscale builders and corporate firm developers by assisting and enhancing their ability and competence to deliver houses or services.

Over the years, it has become increasingly difficult for housing supply to keep pace with demand, and housing conditions continue to worsen in the face of ever increasing urban population in the fast growing cities around the world. It is apparent that a realistic strategy has to be put in place if the housing challenge is to be met. By realising that the state of housing provision is largely inefficient, housing policy emphasis shifted from state provision towards the encouragement of private sector participation in housing development (Israel, 1990; World Bank, 1988). This, as observed by Baken and Linden (1993) and Pugh (1994), could arguably be linked to the changing international response to the global housing challenge resulting largely from the increasing economic liberalism. 
This view was supported by Ogu and Ogbuozobe (2001). They observed that, provideroriented approaches, such as public housing strategies, have failed to meet the housing needs of the vulnerable low-income households. These are the sets of people who require accommodation most. This has resulted in developing countries governments' inability to finance housing schemes.

The failure of the provider paradigm has led to the advocate of enabling paradigm. The World Bank's policy on housing identified seven enabling mechanisms (World Bank, 1993). The importance of the Bank's policy is worth noting here because of its influential position in shaping housing policies, also because it reflects economic ideas inherent in contemporary global economic system.

The seven enabling instruments include:

- the rights to own and freely exchange housing through security of tenure;

- development of mortgage finance and access to housing finance by the poor;

- well targeted, appropriate and rationalised subsidies.

- provision of infrastructure for residential land development;

- land regulation to ensure housing supply;

- development of the building industry by removal of constraints on local production of materials; and

- competition/institutionalisation of frameworks for coordinating various segments of the housing sector.

These policies tend to be tailored to the capitalist (organised) mode of production. The policies are not fully adopted or practiced especially in some developing countries, particularly with regards to land regulation. Ensuring housing supply and the development of mortgage finance for the low-income earners is thus problematic.

As observed by the UN-HABITAT (2003), only very few fortunate countries find themselves well integrated into the flow of global economic systems. A significant percentage of humanity today is being relegated to large and ever expanding informal settlements that span vast regions of the developing countries. The report observes that, 'instead of being a focus for growth and prosperity, the cities have become a dumping ground for a surplus population'. As the cities continue to absorb excess population, it becomes increasingly difficult to cope with the provision of adequate housing and appropriate facilities. The capacity to, effectively, cope with the production of housing is underpinned by the efficient and effective production factors that determine the modes of construction.

It is essential to understand government strategies as explained through the housing production paradigm to facilitate housing production. However, the pluralist view as advanced earlier by Turner and Fichter's (1972) also has relevance in the contemporary context. It provides a broader perspective of housing the poor in sub-Sahara Africa. From the pluralist perspective, there was a need to see beyond the assistance and direct involvement of government to fully understand how the poor's housing needs are met. In this regard, it is imperative to engage the capacity of the poor to build cheaper and better homes than what could be offered by government and the corporate establishments (Ahmad, 1989; Turner and Fichter, 1972; Yeboah, 2005). The interplay of the enabling and provider paradigm in parallel with incremental self built effort sets the context for understanding how different categories of builders pursue their strategies to build. 


\section{Research Method}

The method includes an overarching synthesis of past studies on factors of housing production in Lagos. In parallel, it also involves visits and interviews with some selected developers and agencies to allow a deeper engagement with their activities. This is, in addition to the direct observation, and interviews through purposive selection of some autonomous (on-site) builders to enable better understanding of their activities. The data collection and analysis are largely qualitative and descriptive rather than quantitative. The structured interview component with the registered builder was undertaken with participants from a universe of 49 registered developers in Lagos. These were identified through the Real Estate Development Association of Nigeria (REDAN) list. A stratified sample of 15 developers was selected. The selection process involved a purposive multistage selection (Bryman, 2004) of the registered developers.

With the registered developers and builders, the first stage involves stratifying those on the register along the total number of annual units produced. Three categories were isolated through this procedure. The second stage includes simple random selection, without replacement, among the three categories. The selected developers were subsequently interviewed. In this regard, the process of sourcing and deploying the factors of production were discussed and analysed. With this approach, it was possible to classify the developers along their motive for housing production set against their housing production outputs.

The initial research design was to collect information on the components of profit from the developers and use this to infer the returns on the production factors. This was somewhat difficult because the respective developers were reluctant to align with this approach. They felt this would expose their strategies to their competitors. To work around this, the strategy was changed to the assessment of what is considered most important among the factors: land, labour and capital in determining their profit.

With the on-site incremental builders, Lagos was partitioned along the development corridors: Lekki-Epe, Badagry, Ikorodu-Agbowa, Mowe-Ibafo and the Sango axes. The strategies involve direct observations of housing construction and related activities along these axes. This is complemented with unstructured interviews of at least one on-site builder in each of the axes.

The last step involved the synthesis of all the studies to develop a framework for understanding housing production modes. The framework provided structure for the examination of the different clusters of developers and builders. 


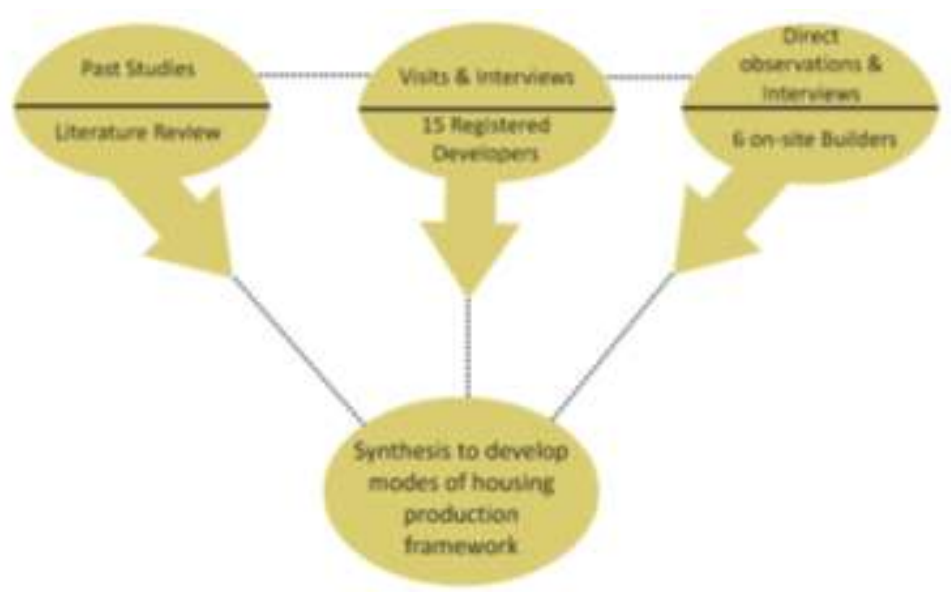

Figure 1: Research design

The research design (Figure 1) provides an opportunity to classify the developers and builders along their motives mediated by the utilisation of the production factors (land, labour and capital).

\section{Study area: Lagos}

Lagos is one of the fastest growing world mega-cities. It is unique in sub-Sahara Africa in terms of geography, population (densities, structure and composition), and the concentration of urban slum populations. This uniqueness might be a limitation in generalising results for the other developing countries. Notwithstanding, it provides context for empirical analysis to gain an improved understanding of different modes of housing production in developing countries.

Lagos is located on the west coast of Africa in south-western part of Nigeria (Figure 2). In terms of land supply for housing production, water and wetlands cover substantial parts of the total land area: 12\% is subject to seasonal flooding (Lagos State Government, 2006). The volume of rainfall in Lagos contributes significantly to making substantial percentages of the metropolis floodable, and consequently reduces the developable areas for housing production. 


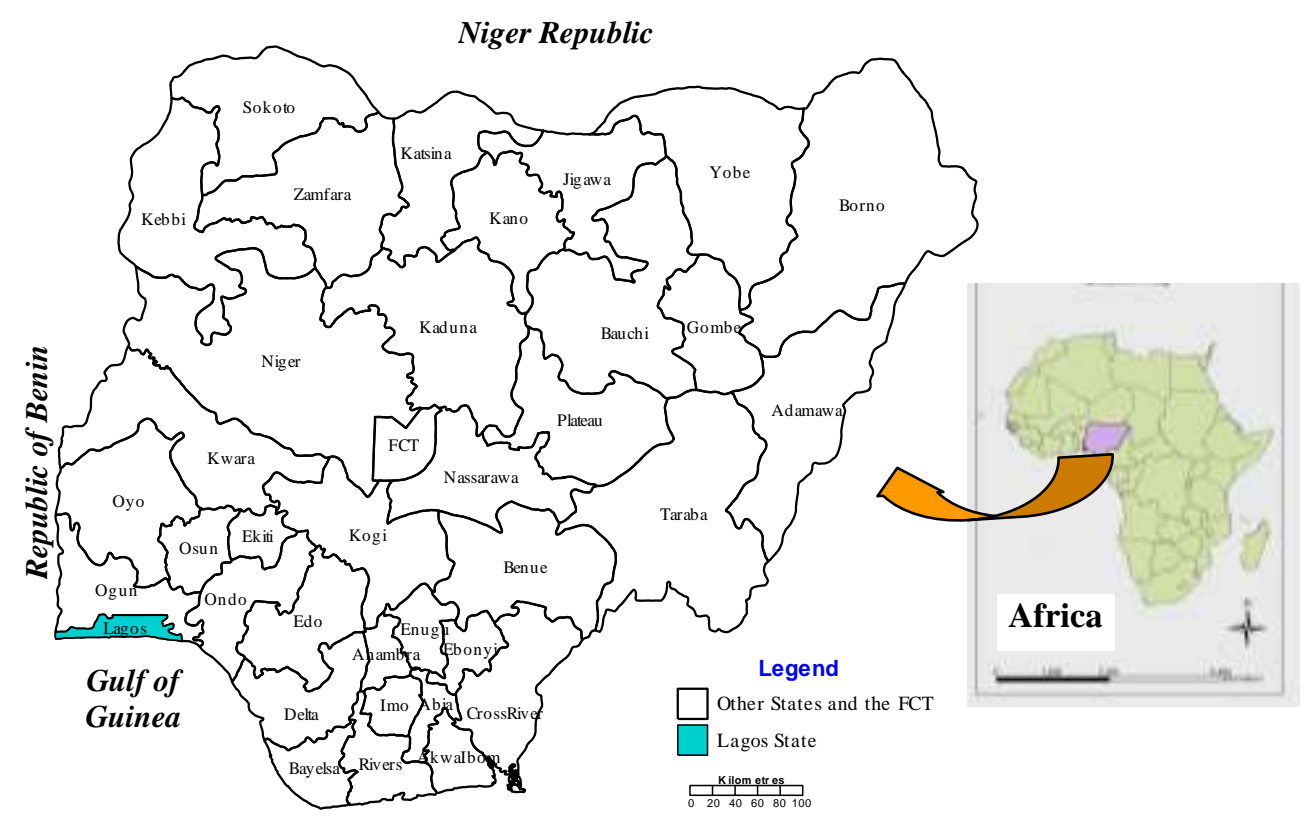

Figure 2: Map of Nigeria showing Lagos State (Lagos State Government, 2006)

Generally, for land to be considered available for housing development, in the official conventional sense in Lagos, it must have physical quality or appropriate improvements sufficient to support corresponding physical development. The developers of this land must possess ownership rights that are consistent with the provisions of the Land Use Act of 1978 and all the subsequent amendments.

Land supply has been significantly influenced by these basic requirements, especially in meeting the legal requirements and has impacted on its availability. The limited availability of land is more intense in a wetland dominated coastal city like Lagos. A general understanding of the geography of Lagos reveals that Lagos total geographic area is $3577.28 \mathrm{~km}^{2}$. Water body accounts for $29.8 \%$ of this; while $60 \%$ of the remaining areas are wetland and remotely detached by creeks and lagoons (Lagos State Government, 2006). In the words of Mathema (2008:2), 'the ground in many of these areas is like a wet sponge, unfit for construction, especially the low-cost type of construction (without foundations that are specially engineered for this type of soil)'. Substantial increase of the total developable land requires engineering solutions in the form of canal dredging and sand filling for reclamation of wetlands and lagoons. This peculiarity obviously places high demand on the available parcels and consequently on the land uses and values.

Regarding capital to finance housing production, the developers and builders in Lagos face different challenges in accessing funds. There are considerable difficulties of obtaining long-term loans or mortgage financing. Provision of funds for housing construction has been largely confined to the deposit banks - commercial and merchant banks. Loans through these sources attract interest rates of between 15 and $22 \%$. The open market mortgage rate is $17-18 \%$ (Walley, 2008).

Major problems of mortgage lending market as identified by Omirin and Nubi (2007) and Walley (2008) as involving the general confusion between housing construction loans and mortgage financing and loans. Others include: insignificant contributions from Primary Mortgage Institutions in mobilizing long term finance, and the shift in emphasis to direct 
construction as opposed to the provision of mortgage facilities. The bureaucratic bottlenecks in mobilizing contributions and the disbursement of funds under the National Housing Funds Scheme (NHFS) are equally significant. Most importantly, Omirin and Nubi (2007) observed that title documents - Certificate of Occupancy (CofO), which usually serve as collateral for loans, are extremely difficult to obtain, usually expensive to procure, and out of reach of the poor majority.

The conditions for grant of loans by commercial banks, usually for short terms, and the requirements of long term loans for housing purchase diverge. Against this background, the developers and builders are motivated to produce housing units in the short term if the demand for their products could equally be met in the short term. An implication of this is that the level of profit accruable from engagements motivates those who engage in housing production.

With regards to labour as the third component of production factors in Lagos, construction works are mostly manually carried out with less application of mechanical equipment (Olokesusi and Okufolure, 2001; Udegbe, 2005). Labour contribution as a proportion of construction cost is found to vary with the type of construction technology adopted. It also varies with the proportion of skilled to unskilled (Olumide and Adelore, 2005; Udegbe, 2005). This places a substantial capital outlay on payment of on-site labourers. Availability of labour is thus a significant factor in determining the mode of housing production.

The interactive combination of these production factors (land, labour and capital) substantially mediate governments' housing policies, especially in shaping and aligning with the housing production paradigm (housing delivery strategies). The utilisation of the production factors also impacts the processes of construction as discussed next.

\section{Housing construction modes: understanding the processes in Lagos}

Understanding what determines the returns to the factors of housing production requires understanding of how these factors are deployed in production processes. It is acknowledged that the housing production process varies from country to country, though; it generally follows a common pattern (UN-HABITAT, 2010). Researchers have used different approaches to classify housing production processes using different contexts. Okpala and Aniekwu (1988), classified housing processes as: project conception, project design (including land preparation), and project construction. These classifications are particularly relevant to the developing countries where the majority of dwellings are self built, and owner occupied. In more developed countries and within the organized production sector in developing countries, it could include marketing and sale because of the significance.

If marketing and sales are considered, the processes of producing housing could thus be categorised into four phases: conception and design, land preparation, construction and marketing as illustrated in Figure 3. The initiation of a development project starts from the desire to satisfy a particular need through the construction of a physical structure. This desire is translated through the project design phase into an expression of a spatial form that will satisfy the client's requirements in the most advantageous economic manner. Okpala and Aniekwu (1988) note that the construction phase creates the physical form that satisfies the conception and permits the realization of the design. 


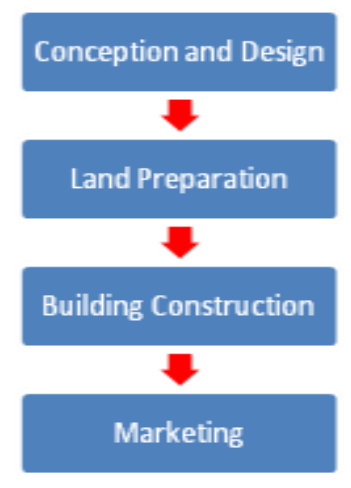

Figure 3: Illustrating housing production processes

(Adapted from Okpala and Aniekwu, 1988)

There are some basic issues involved in understanding housing construction processes as described by Okpala and Aniekwu within the frame of the earlier discussions. It is necessary to considerer how the range of construction processes influences housing outputs by considering returns to the production factors. It is also necessary to consider what could alter the processes to increase the housing output. Before a detailed discussion on this, it is necessary to consider a simple logic with regards to the fundamental principle guiding housing development. The logic is that the main concern for putting into best use the construction inputs or factors starts with the motive for housing development whether it is for asset formation and/or housing services. This motive determines the mode of production and how it is ultimately classified, in this paper, into organised or autonomous sector.

Conceptually, organised and autonomous sectors in construction processes relate to the structure and organisation of developers ${ }^{2}$ as well as the purpose of production. This is closely aligned with the governments' policy structure, in terms of supports for housing production, as explained through the provider and enabling paradigm. Conversely, the provider and enabling paradigm explains the governments' support and policy direction. Organised and autonomous sectors as classified here describe and explore whether housing construction is for investment or is just set to provide housing services or the combination of the two (housing services and/or investment property). The motivation to engage in either of housing services and/or investment property could be closely linked with the anticipated gain (in terms of providing housing services) or anticipated profit (in terms of being investment property). The next discussions offer a brief overview of the profit or gain anticipated by the developers, and demonstrate them as a motivator for housing production.

\subsection{Developer's anticipated profit or gain}

The principle of residual logic of land valuation provides the bases for estimating the developers anticipated profit. This principle is based on the calculation of the amount that house builders can afford to pay for land by reference to the anticipated price they will ultimately realise for housing construction (Baker, 2003). This substantially determines the anticipated profit.

\footnotetext{
2 These are people who invest in and develop the urban or suburban potentialities of real estate, especially by subdividing the land into lots. They might also be involved in the actual construction and sale of houses (organised sector of housing production). It is contextually synonymous with builder in most informal settlements that are predominantly autonomous self built in developing countries depending on the scale and motive of construction
} 
Within this frame, the developer's anticipated profit ranges between the normal and the super profit. This is not expected by the builder/developer to be less than the margin tolerable for housing production to be considered viable. As noted by Adams (2005:25), a 'developer seeks to minimise development costs and maximize development revenues in order to maximize development returns or profits'. The developer's anticipated Profit (P) is thus calculated as the gap between Total Cost $(\mathrm{C})$ and Total Revenue (R). P=R-C. In other words, the anticipated gross development profit might be considered as a portion of the difference between the value of housing output and the cost of producing it. This could be calculated by imputing the; basic construction cost - labour, materials, capital and contractor's ${ }^{3}$ anticipated profit. Land value might be treated as a residue of the total housing value minus all the construction cost. The anticipated developer's profit determines to a large extent the architecture or design of housing which consequently determines the technology of construction. It is worth noting, based on the responses from the interviewees, that there is usually high correlation between the type of designs and the financial resources available to developers. The value of the developer's anticipated gross profit is thought to have significant influences on the motivation for investment property.

Closely related to the developer's profit in determining the viability of housing construction is the anticipated gain. In this case, the anticipated gains are usually unquantifiable, but could be likened to consuming the use value of the dwelling. In some developing countries as noted by Agbola (1990), housing construction, in addition to its economic significance of having exchange value, is considered to confer some social prestige on its owners suggesting an individual is an eminent member of the community. Although this social value might be difficult to measure, however, the desire to engage in housing construction especially by the autonomous self-built developers is directly motivated by this.

For the purpose of this analysis, therefore, it is essential to determine the different categories of developers or builders. As discussed above, the nature of their activities, are observed to reflect the anticipated gain or profit accruable to each of them.

\subsection{Classification of the developers in Lagos}

As found through this study, there are two broad groups of developers in Lagos according to their level of organisation and motive. These are described as organised (mostly investment) and autonomous (mostly consumption) sectors (Figure 4).

\footnotetext{
${ }^{3}$ Contractors are builders that are directly involved in the physical construction and the coordination of all the factors of housing construction.
} 
Figure 4: Housing construction processes - the organised and autonomous modes of production

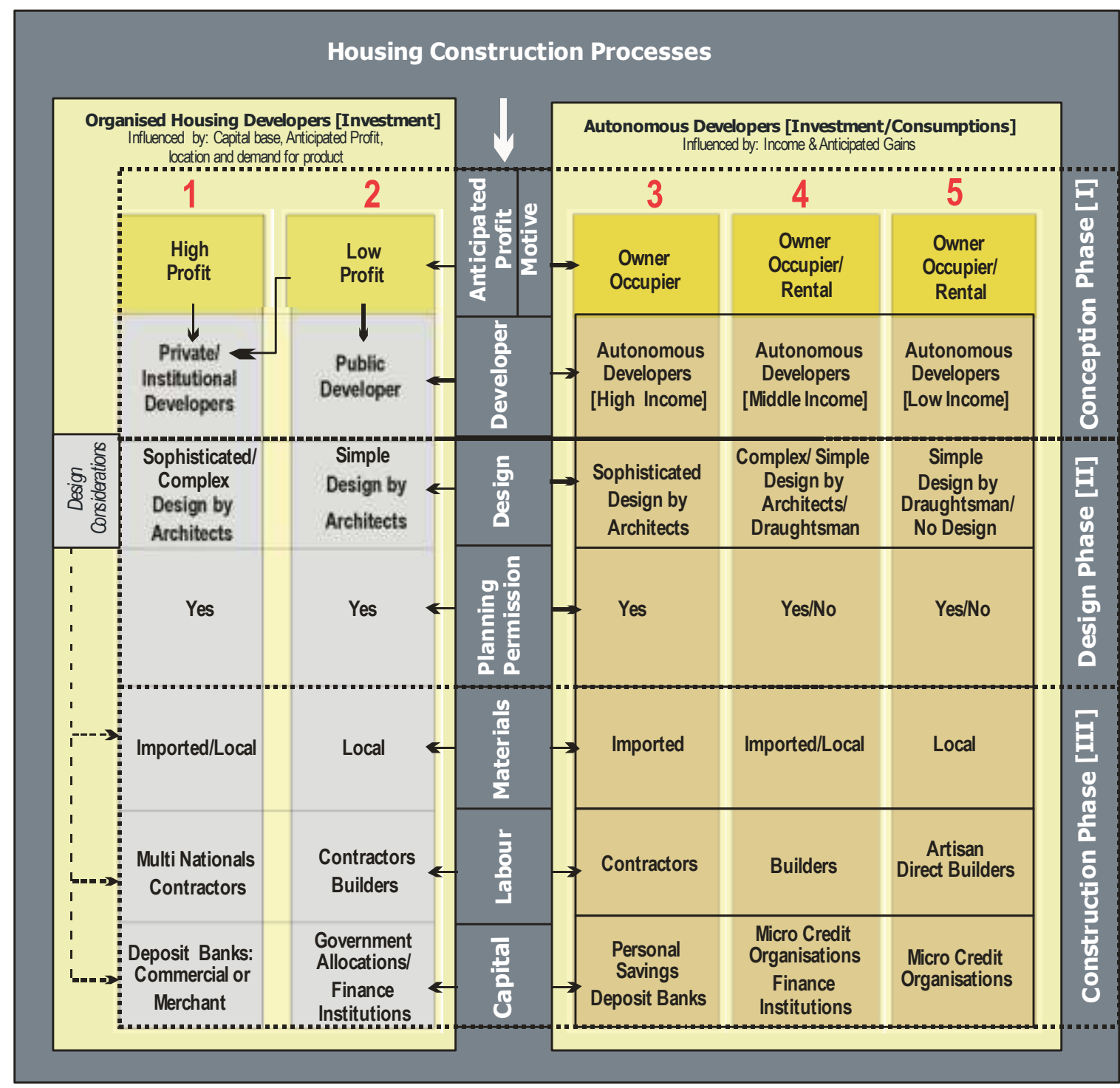

The organised housing production sectors are substantially made up of groups of investors largely motivated by profit making and are constantly determined to get better deals than their competitors. Their engagement in housing construction is usually determined by the minimum profit anticipated from housing development.

The autonomous housing production consists of individual developers or builders motivated to develop dwellings in the form of both asset formation and housing services for their exclusive use.

From these broad groups, three categories of developers in the organised sector, as determined by their investment motives for producing housing, were identified. These are public, private estate and institutional developers (each of these corresponds to a particular production process, although there might be overlaps in some cases). The three categories could be sorted into two classes: intended low profit, and combinations of high and low profits.

To progress this analysis, the starting point is to recognise that there are various means (tracks) by which individuals within a particular jurisdiction can pursue their strategy to 
produce housing. This is found to be dependent on the prevailing land delivery process, mediated by the political, economic systems, level of technological and economic developments. This also reflects the institutional and cultural structures of the people. Literature and findings from the interviewed participants have shown two main production tracks: organised and autonomous. In between these are variations that range from extreme organised to extreme autonomous or self built tracks (Figure 4). The variation is determined by the level of authorised and unauthorised housing construction. These get different forms and vary not only from country to country but even from city to city within a country (UN-HABITAT, 2010). The specific level of development and particular circumstances in Lagos provide sufficient context in this regard.

As shown in Figure 4, five different construction sectors and corresponding organisational structures emerge from these classifications. These are; private estate and institutional developers (high or low anticipated profit), public developers (low anticipated profit), autonomous developers (high income-owner occupier), autonomous developers (middle income-owner occupier/rental), autonomous developers (low income-owner occupier/rental). Each of these sectors has its corresponding production processes. They are now discussed in the following sections.

\subsubsection{Private Estate Developers (High Anticipated Profit)}

The private estate developers are private groups of individuals or corporate establishments registered as limited liability companies with the primary aim of providing housing at commercial rates. It is worth noting that most of the developers are by themselves contractors (builders), while some engage the services of dedicated contractors and supervise their activities. As observed during the interview, most of them are registered with the Real Estate Development Association of Nigeria (REDAN). In Lagos, 49 out of more than 150 registered nationwide are fully operational. Like any other private limited liability companies, the motive for their establishment is primarily to make a profit. The popularity of residential real estate as a lucrative area of asset formation capable of yielding better returns on investment in Lagos is a relatively recent development. It started in the late 1980s as demands for housing increased due to high rates of urbanisation coupled with the disengagement of governments from the direct provision of housing. They provide housing of different types and at different scale in different locations within Lagos. They do not receive any direct form of financial assistance from the government. They are, therefore, expected to mobilise the factors of production; land, labour and capital as effectively and as efficiently as their capacity permits in order to produce housing in a competitive manner among other estate developers.

The process of housing production starts with the highly challenging procedure of acquiring a sizable parcel of land for the development of residential estate or separate housing units. Obtaining land in desirable locations that will be attractive to prospective buyers remains the greatest challenge to the developers as observed during the survey. The size of residential estate that is eventually developed usually varies with the financial capacity of the estate developers as well as the availability of land. The simplicity or sophistication of design is generally dictated by the anticipated demand for units. This is also a function of the anticipated profit. All these factors determine the technology of construction and the type of labour that will be engaged.

Most private developers utilise the 'subscriber system' whereby money for projects is generated from individual intending buyers as deposit before construction starts. In some other instances, loans are obtained from banks and corporate establishments, especially 
for the provision of services like roads, drainage and electricity that will serve the estate. The major source of loans is from commercial banks at excessively high interest rates, between 15 to $22 \%$, and on stringent conditions for repayment. In the final analysis, the ability to secure adequate finance as part of the whole process determines the total housing units that are eventually produced.

\subsubsection{Institutional developers (low anticipated profit)}

The two institutional developers LSDPC and FHA were initially established by the government to provide housing for the public, especially the low income groups, at a reduced rate relative to the market value. The two institutions, as initially established, were directly involved through government allocations in the actual production of houses. They engaged and supervised the contractors on the site, in what was then described as mass housing provision.

With the shift in housing policy, government reduced the direct financial supports and instead concentrates or restricts its supports to land provision. With this development, the institutions or agencies need to borrow money from banks and corporate establishments or at times collaborate with private sector agencies to produce housing. At present, their operations, apart from land acquisition processes, are similar to the private developers as described above. Given governments' roles in providing land for institutional developers they have comparative advantages over the private developers. Some people have, therefore, argued that the unit cost of their houses should be lower, given this level of institutional supports.

The only public developer that remains in the business of housing provision is the Lagos State Ministry of Housing. The ministry is directly involved in the actual construction of buildings targeted at providing for the low income earners, with special preference for civil servants working with the Lagos State government. The sales of units are usually subsidised, sometimes below the market value. However, since the role of government has shifted from the provider and now parallel to the enabling (supporter) approach, reflecting the trend all over the world, the numbers of units provided through this means have been reduced significantly over the years.

Overall, the efforts of government through the direct involvement at present are insufficient to produce the significant proportion of houses required to meet the need of the public. At the same time, other efforts by private developers are also considered inadequate, because most of the developers are interested in the pursuit of their profit.

As a result of this inadequacy, autonomous developers construct the majority of houses in Lagos. They constitute the greatest proportion of informal housing. This study identified three categories in this regard as discussed next.

\subsubsection{Autonomous developers (high income-owner occupier)}

These are individual builders motivated to develop housing for their exclusive use. The types of houses are predominantly mansions and detached houses in a large compound with corresponding facilities and services like swimming pools, private garden and playground. Plot size is generally $1000 \mathrm{~m}^{2}$ or more. Land for this type of development is usually acquired through both the formal and the informal sources, but developers generally have title documents and necessary planning permission required. The house owner usually engages the services of contractors in the actual construction. Funding is 
usually from the savings of the owners with supports from loan that are usually obtained from the commercial banks.

\subsubsection{Autonomous developers (middle income-owner occupier/rental)}

These are autonomous builders that develop residential apartments for their accommodation in the form of both asset formation and housing services. This is possible because building as a commodity has both use value and exchange value. Parts of it are leased to others (tenants) and consequently generate returns on assets in the form of flow of consumption. Some of the developers in the high income category may equally be engaged in housing production, in this form. They usually develop semi-detach residential apartments of varying sizes, ranging from 2 to 4-bedrooms. The units are mostly rental apartments and are generally, not for sale. Significant proportions of these are situated on informal land and usually lack the necessary use and development rights as stipulated by the planning authorities.

\subsubsection{Autonomous developers (low income-owner occupier/rental)}

These are largely dominated by the owner-occupier autonomous builders. They are often described as on-site builders. The buildings are developed on an instalment bases, tailored to the builders' tastes and financial capabilities. The buildings are mostly of low quality and informal. As observed by (UN-HABITAT, 2010), access to land is crucial in informal housing processes. Circumstances vary depending on settlement structure. Some squat on public land while some informal settlements thrive on private land.

The classification of developers as discussed presents a brief representation of modes of housing production in Lagos. The following discussion demonstrates the utility of classifying builders along autonomous and organised modes. It also shows how this could help policy makers, in parallel, to facilitate more housing delivery.

\section{Discussions and Summary}

Following from the framework as discussed in section 5, developers are classified along different categories to be able to: identify different players; their motives, the challenges they face in providing housing, their strength and weaknesses.

As revealed through the findings, it is obvious that builders are driven by several factors. For example, the private estate developers, the institutional developers - LSDPC, and the Federal Housing Authority (FHA) are driven by profit making. The autonomous builders are motivated to satisfy one of the basic human needs (provision of shelter) while others within this group are motivated by investment drive to augment their income. The public developer (Lagos State Ministry of Housing) was established to provide housing units that are intended to be service provision oriented. Thus, the units constructed are supposed to be provided to the end users at a much subsidised rate. Each of these targets different markets and meets different needs.

However, some of the main concerns are: whether the organised public developer actually provides housing at such subsidised rate as initially conceived; and whether the strategies of private and institutional developers/builders will sufficiently facilitate production of housing at scale. A detailed assessment of these issues is outside the scope of the present analysis. It, however, provides the basis for understanding the strategies adopted, by individuals to meet their housing requirements as well as policy options available for government to facilitate housing production 


\section{A. Assessment of governments' policy options}

Through different policy options, government is meant to oversee and coordinate the activities of those different builders. Government actions need to be refocused to, adequately, guarantee sufficient housing are produced.

An overview assessment of the activities of public developer with regard to the processes of building allocation reveals that they target making profit contrary to their mission statement that they are not-for-profit providers. Apart from the bureaucratic procedures for allocating completed houses, it was discovered that the prices those houses are offered are usually beyond the reach of most prospective buyers. It is obvious from this and the preceding analyses that pursuing the provider strategy will not support production of housing at scale.

However, since each additional units of housing contributes to populating the stock, it is consistent with logic to argue that it still remains a strategy to increase housing stock. Contributions from this sector should, therefore, be made more efficient. As a result, there is a lot of scope, for the government to regulate the allocation process and make it more transparent. This becomes necessary to ensure that the interests of the poor, low income working population are protected.

Given the inability of the provider approach to provide adequate housing for the majority of residents, it will be expected that the government will direct its efforts to the enabling approach. In this regard, more efficient land release, through effective provision of infrastructure to make developable land available will be required. To achieve this is also challenging. This mostly results from the process of land release and the associated costs of making such land developable.

\section{B. Refocusing the land release policy}

From the preceding analyses, it could be inferred that, most of the profits accruable to profit driven developers/builders come from the land component. For example, in the case of the private estate developers and the LSDPC, their expectations to make high or low profit, from the units constructed, are largely determined by the location, land value and the level of competition for land by other developers in such locations. As it is the case in Lagos, the developers usually target where normal or preferably super profit could be made and continually scramble for high valued neighbourhoods or locations. It was also discovered that most of the time the super profit is obtained through the process of acquiring land for housing development. The observation and analyses support the past isolated studies, that the availability of land is a major determinant of housing cost. This further attested to a high ratio of land to capital improved value (capital and labour share) of the production cost in the study area.

There is a lot of scope for the government to regulate this process, and prevent prospective buyers from being taken advantage by the developers. In this regard, land management policies, land administration processes (especially the development assessment requirements and procedures) should be streamlined for efficiency and effectiveness.

\section{Refocusing the enabling approach}

There is a compelling need to exercise caution about the absolute reliance on the private sector as an enabler for effective housing delivery. As an example, most organised 
developers usually base their investment strategies not just on minimum anticipated profit but most often target super profit. This is used to measure the threshold for the determination of the viability of the project in the first instance. If this could not be guaranteed, then it will be a significant disincentive for housing production.

Most often the set threshold is usually beyond the reach of the poor majority. The organised developers usually target where preferably super profit could be made and continually scramble for these areas. The implication is that the autonomous on-site builders, (that constitute the majority - middle and low income groups) are often displaced by the investors in a continuous competition for space in different locations within Lagos. The recent trend as observed during this study was a massive rush for land acquisition along the development axes. This could be considered as an unprecedented land banking venture by the organised private investors making it more difficult for autonomous on-site builders to have access to land. It is thus essential to strike a balance between what is considered appropriate in a particular circumstance. This is necessary to make appropriate policy decisions as it is the case in Lagos.

In summary, the availability of land, capital, and to some degree labour, have shaped the housing market in Lagos. As revealed through this study, securing the right of occupancy and development rights has remained a considerable challenge in housing production. Contrary to the popular belief that finance is a serious impediment (Ikejiofor, 1997; Onibokun, 1983, 2003; and Walley, 2008). Most of the on-site builders interviewed are of the opinion that they could build their homes within the available resources. This is provided they could be guaranteed secured tenure while at the same time requesting that government should relax the development approval procedures. This might raise another issue of quality and standards which is outside the scope of the present discussions. It is recommended that more efficient land supply to the autonomous on-site builders should be given adequate attention by policy makers.

\section{Conclusions}

The study investigated how housing developers/builders and government (through policies) impact modes of housing production in Lagos. From the overview, through the existing literature, and finally from the perspective of empirical stud; it was evident that government needs to refocus its attention regarding, land management policies such as land-use and land-development rights.

It could be inferred, therefore, that land and land related issues are important considerations in housing provisions relative to other basic production factors like labour, materials and finance. On the bases of these findings, there is evidence to support the view that land supply could make the most significant policy impact relative to other housing production factors. In this regard, it is considered to have the potential to alter significantly how housing production could be effectively and efficiently organised. From these observations, it is necessary to consider the returns to land in a way to adopt appropriate policy measures. This is essential to enhance further housing production in Lagos and by extension other developing countries with similar circumstances.

\section{Acknowledgement}

The authors would like to acknowledge the supports provided by the Australian Research Council through a linkage project on National Infrastructure for Managing Land 
Information (NIMLI) and with the collaboration of the industry partners: Land Victoria, Land and Property Management Authority, New South Wales, Landgate - Western Australia and PSMA. Also acknowledged are the constructive comments from members of CSDILA and the supports from the University of Lagos at the early stage of the research. However, the views presented are those of the authors and not of the project partners.

\section{References}

Adams, C. D. (2005). Urban Planning and the Development Process. London and New York: Routledge.

Adeola, B. (2006). Imperatives for Mass Housing in Lagos State - The LSDPC Medium Income Housing Approach. Paper presented at the 2000 Annual Conference and AGM of the Association of Consulting Engineers, Nigeria (ACEN).

Adeola, B. (2008). Our Collective Responsibility: Ogun State. Regional Development Strategy. Lagos: Comprehensive Project Management Services. .

Agbola, T. (1988). The housing construction process in Nigeria: Implications for urban growth and development. Cities, 5(2), 184-192.

Agbola, T. (1990). Affordability and Cost Recovery in Shelter Projects: The Case of Nigeria. Third World Planning Review, 12(1), 59-73.

Ahmad, A. M. (1989). Housing submarkets for the urban poor - the case of Greater Khartoum, the Sudan. Environment and Urbanization 1(2), 50-59.

Aina, T. A. (1988). The Construction of Housing for the Urban Poor of Lagos. HABITAT International 12(1), 31-48.

Baken, R. J. and Van der Linden, J. (1993). 'Getting the Incentives Right': Banking on the Formal Private Sector. (HIS Working Paper Series No.5),

Baker, K. (2003). Review of Housing Supply Interim Report -Analysis. Retrieved from http://image.guardian.co.uk/sys-files/Guardian/documents/2004/03/17/Barker.pdf.

Bryman, A. (2004). Social Research Methods. Oxford United Kingdom: Oxford University Press.

Egbu, A. U., Olomolaiye, P. and Gameson, R. (2008). A neo-institutional economic critique of the system for allocating urban land and development rights in Nigeria. Habitat International 32, 212-135.

Hamdi, N. (1995). Housing Without Houses: Participation, Flexibility, Enablement: Intermediate Technology Publications.

Ikejiofor, U. (1997). The Private Sector and Urban Housing Production Process in Nigeria: A Study of Small-Scale Landlords in Abuja. Habitat International 21(4), 409-425.

Israel, A. (1990). The Changing Role of the State: Institutional Dimensions: World Bank.

Keivani, R. and Wernab, E. (2001). Modes of Housing Provision in Developing Countries Progress in Planning 55, 65-118.

Lagos State Government. (2006). Lagos State Regional Plan Review. Lagos.: Ministry of Physical Planning and Urban Development.

Mathema, A. (2008). Slums and Sprawl in Lagos: The Unintended Consequence of 'WellIntended' Regulation.,

Ogu, V. I. and Ogbuozobe, J. E. (2001). Housing Policy in Nigeria: Towards Enablement of Private Housing Development. Habitat International 25(2001), 473-492.

Okpala, D. C. and Aniekwu, A. N. (1988). Causes of high costs of construction in Nigeria. Journal of Construction Engineering 114(2). 
Olokesusi, O. and Okufolure, A. (Eds.). (2001). An Overview of Factors Influencing the Pace of Building Starts in Nigeria, : A Publication of Federal Ministry of Works $\&$ Housing and NISER -2001.

Olumide, O. and Adelore, C. (2005). New Concepts for Sustainable Housing Delivery. University of Lagos. . Retrieved from www.unilag.edu.ng/publication/opendoc.php?sno=1786\&doctype $=$ doc $\&$ docname $=\$-$

Omirin, M. and Antwi, A. (2004). Informality, Illegality and Market Inefficiency: A Case for Land Market Deregulation in Accra and Lagos Retrieved from http://www.rics.org/site/download_feed.aspx?fileID=2524\&fileExtension=PDF

Omirin, M. M. and Nubi, T. G. (2007). Role of Primary Mortgage Institutions in Housing Delivery. The Housing Finance International, 22(1), 52-56.

Onibokun, A. G. (1983). Issues in Nigerian Housing. Ibadan: NISER.

Onibokun, A. G. (2003). The Problem of Housing Construction in Nigeria. Ibadan: University of Ibadan Press.

Pugh, C. (1994). Housing Policy Development in Developing Countries: The World Bank and Internationalization 1972-93. Cities, 11(1), 159-180.

Turner, J. C. and Fichter, R. (Eds.). (1972). Freedom to Build. New York: Macmillan.

Udegbe, M. I. (2005). Labour Force Output on Plastering Activities in Edo State. The Professional Builders. Journal of the Nigerian Institute of Builders 34-41.

UN-HABITAT. (2003). The Challenge of Slums - Global Report on Human Settlements 2003. London and Sterling, VA: Earthscan Publications.

UN-HABITAT. (2010). A Practical Guide For Conducting: Housing Profiles-Supporting Evidence-Based Housing Policy and Reform UNON. Nairobi: Publishing Services Section.

UNCHS. (1990, 12 April, 2011). Global Strategy for Shelter to the Year 2000. from http://www.greenstone.org/greenstone3/nzdl;jsessionid=105317B3376228F652AE F587C9147CC6 $? \mathrm{a}=\mathrm{d} \& \mathrm{c}=\mathrm{cdl} \& \mathrm{~d}=\mathrm{HASH} 01 \mathrm{a} 05 \mathrm{fd} 0 \mathrm{c} 88 \mathrm{aea} 02668205 \mathrm{ab} \& \mathrm{dt}=$ hierarch y\&p.a=b\&p.s=ClassifierBrowse

UNCHS. (1991). Assessment of Experience with The Project Approach to Shelter Delivery for the Poor United Nations Centre for Human Settlements Habitat.

Walley, S. (2008). Nigeria Financial System Strategy 2020: Housing Finance; Strengthening Financial Sectors. First Initiative

Wood, G. and Ong, R. (2010). Western Australia Research Centre Factors shaping the decision to become a landlord and retain rental investments for the Australian AHURI Final Report No. 142. Retrieved from http://www.melbourneinstitute.com/downloads/hilda/Bibliography/Other_Publicat ions/Wood_etal_Factors_shaping_the_decision_to_become_a_landlord_and_retai n_rental_investments.pdf

World Bank. (1988). World Development Report 1988. New York: Oxford University Press for the World Bank.

World Bank. (1993). Housing: Enabling Markets to Work. Washington, DC: World Bank. Yeboah, I. E. (2005). Housing the urban poor in twenty-first century Sub-Saharan Africa: Policy mismatch and a way forward for Ghana. GeoJournal 62, 147-161. 
Appendix I (Not to be published)

Real Estate Developers Associations of Nigeria (REDAN) List of Practisioners in Lagos

\begin{tabular}{|c|c|c|c|}
\hline S/N & Companies & Head Office /Address & $\begin{array}{l}\text { Units in } \\
\text { Portfolio }\end{array}$ \\
\hline 1 & AKI ENGR. NIG. LTD & $\begin{array}{l}\text { 2, Olayemi Street, Nobi, Surulere P.O.Box } \\
\text { 4655, Surulere }\end{array}$ & 58 \\
\hline 2 & $\begin{array}{l}\text { AKN INVESTMENT } \\
\text { LTD. }\end{array}$ & $\begin{array}{l}\text { Suit 15, Ikeja Way Shopping Complex, } \\
\text { Dolphin Estate, Ikoyi Tel: 01-2671617, } \\
\text { 2673160, 08033068835. }\end{array}$ & 75 \\
\hline 3 & ALPHA WORKS LTD. & $\begin{array}{l}\text { 18B, Lavander Close MKO Garden P.O.Box } \\
\text { 1846, Ikeja, Lagos. Tel: } 471330 \text {, }\end{array}$ & 87 \\
\hline 4 & $\begin{array}{l}\text { ANSWER CALL } \\
\text { PROPERTIES DEV. CO. } \\
\text { LTD }\end{array}$ & $\begin{array}{l}\text { 15, Adeniran Ogunsanya Str. Surulere, Lagos } \\
\text { Tel: } 5851092 \text {, Fax: } 5851635\end{array}$ & 35 \\
\hline 5 & BELTECO ENGR. LTD. & $\begin{array}{l}\text { 248, Murtala Mohammed Way. P.O. Box } \\
\text { 3072, Yaba-Lagos }\end{array}$ & 220 \\
\hline 6 & $\begin{array}{l}\text { BUSINESS } \\
\text { CONTACTING LTD }\end{array}$ & $\begin{array}{l}\text { Maritime House, } 1 \text { st Floor, } 4 \text { Burma Road, } \\
\text { P.O. Box 3321, Apapa Tel: } 5872875\end{array}$ & 24 \\
\hline 7 & CAMBIAL LIMITED & $\begin{array}{l}\text { 7, Jide Ayo Close, omole Estate Ikeja. Tel: } \\
7740652\end{array}$ & 76 \\
\hline 8 & $\begin{array}{l}\text { CITY DEV. } \\
\text { PROPERTIES LTD. }\end{array}$ & $\begin{array}{l}\text { No } 19 \text {, Yesufu Sanusi Street, Surulere } \\
\text { P.O.Box 2473, FESTAC Town }\end{array}$ & 104 \\
\hline 9 & $\begin{array}{l}\text { COMPROMOR NIG. } \\
\text { LTD. }\end{array}$ & $\begin{array}{l}\text { No 71, Oworonshoki P.O. Box 4812, MM } \\
\text { International Airport Ikeja }\end{array}$ & 54 \\
\hline 10 & $\begin{array}{l}\text { CORNERSTONE } \\
\text { CONSTR. (NIG) LTD }\end{array}$ & $\begin{array}{l}\text { 3, Ope oredugba Close bank Anthony Way, } \\
\text { Ikeja. Tel: } 4975563\end{array}$ & 321 \\
\hline 11 & $\begin{array}{l}\text { CRITTAL ENGR. } \\
\text { SERVICES }\end{array}$ & $\begin{array}{l}\text { 330/332, Agege Motor Road, Mushin P.O. } \\
\text { Box 28, Ikeja, } \\
\text { Tel: 4521155-7 }\end{array}$ & 67 \\
\hline 12 & $\begin{array}{l}\text { DAPAGE VENTURES } \\
\text { LTD. }\end{array}$ & $\begin{array}{l}\text { Suite } 1014,10^{\text {th }} \text { Floor, Western House, Broad } \\
\text { Street. Tel } 2646320\end{array}$ & 87 \\
\hline 13 & DOMART INVEST. LTD. & $\begin{array}{l}\text { No 56, Charles Amu street, P.O.Box } 8313 \text {, } \\
\text { Tel: } 4935494\end{array}$ & 122 \\
\hline 14 & DOSIGAM VENTURES & $\begin{array}{l}\text { Destiny Suite, } 19^{\text {th }} \text { Floor (Great Nig. House) } \\
47 / 57 \text { Martins Str. P.O. Box } 72393 \text {, V/I Lagos }\end{array}$ & 88 \\
\hline 15 & DRAYTON (NIG) LTD. & $\begin{array}{l}\text { 30, Rhodes Crescent, Apapa, Lagos Tel: } \\
5452748\end{array}$ & 95 \\
\hline 16 & $\begin{array}{l}\text { ECO BUILDING } \\
\text { SYSTEMS NIG. LTD. }\end{array}$ & $\begin{array}{l}\text { 10A, Anifiwoshe Street, Off Adeola Odeku, V/I } \\
\text { Tel: } 2611709\end{array}$ & 45 \\
\hline 17 & ELDA NIG. LTD & $\begin{array}{l}\text { 12, Olaribori Str. Behind Alade Mkt. Off Allen } \\
\text { Avenue P.O. Box 4136, Ikeja. Tel. 4966637, } \\
4920788\end{array}$ & 36 \\
\hline 18 & FHOMO NIG. LTD. & $\begin{array}{l}\text { 15, Ola Ayinde Str. Off Mobolaji Bank } \\
\text { Anthony Way P.O. Box 2193, Ikeja Tel: } \\
\text { 4936131, } 08023309997\end{array}$ & 64 \\
\hline
\end{tabular}




\begin{tabular}{|c|c|c|c|}
\hline 19 & $\begin{array}{l}\text { FIDDY VENTURES NIG. } \\
\text { LTD }\end{array}$ & $\begin{array}{l}\text { 27, Adekunjo Str. Off Kollington B/Stop } \\
\text { Abeokuta Expressway, Alagbado. P.O. Box } \\
\text { 15950, Ikeja Lagos }\end{array}$ & 67 \\
\hline 20 & $\begin{array}{l}\text { FIDUCIARE AFRIQUE } \\
\text { CAPITAL MARKETS } \\
\text { LTD. }\end{array}$ & 3B, Awori Crescent, llupeju-Lagos & 344 \\
\hline 21 & $\begin{array}{l}\text { FIRST ATLANTIC } \\
\text { REALITY CO. LTD. }\end{array}$ & $\begin{array}{l}\text { 17, Alh. Jimoh Str Off Adeniyi Jones Avnue, } \\
\text { Ikeja Lagos. Tel: } 4936850\end{array}$ & 156 \\
\hline 22 & $\begin{array}{l}\text { FOLUSO PROPERTIES } \\
\text { LTD. }\end{array}$ & $\begin{array}{l}\text { UBA House, 2nd Floor, 22B Idowu Taylor Str. } \\
\text { Victoria Island }\end{array}$ & 34 \\
\hline 23 & $\begin{array}{l}\text { FUNDSWORTH } \\
\text { LIMITED }\end{array}$ & $\begin{array}{l}\text { 51A, Apongbon Str. Lagos P.O. Box } 74424, \\
\text { V/I Tel. 2644002, Fax: } 2662289\end{array}$ & 55 \\
\hline 24 & $\begin{array}{l}\text { GOOD HOMES } \\
\text { ESTATE LTD }\end{array}$ & $\begin{array}{l}\text { 270, Ikorodu Road, Obanikoro, Lagos. Tel: } \\
4934484\end{array}$ & 78 \\
\hline 25 & $\begin{array}{l}\text { GUSTAKOM } \\
\text { COMPANY LTD. }\end{array}$ & $\begin{array}{l}\text { No } 19 \text {, Yesufu Sanusi Street, Surulere } \\
\text { P.O.Box 2473, FESTAC Town }\end{array}$ & 45 \\
\hline 26 & $\begin{array}{l}\text { HERON } \\
\text { ENVIRONMENTAL } \\
\text { CONSULTANTS \& } \\
\text { ENGR. }\end{array}$ & $\begin{array}{l}\text { 4, Ladipo Oluwale Str. Off Adeniyi Jones, } \\
\text { Ikeja, Lagos. } \\
\text { Tel: } 4939264\end{array}$ & 37 \\
\hline 27 & $\begin{array}{l}\text { HYDRA PROPERTIES } \\
\text { LTD }\end{array}$ & $\begin{array}{l}\text { Adata plaza, } 10 \text { Balarabe Musa Crescent, V/I } \\
\text { P.O. Box 3599, Apapa Lagos Tel: } 2619424\end{array}$ & 125 \\
\hline 28 & KNIGHT FRANK & $\begin{array}{l}\text { 24, Campbell Street, P.O. Box 221, Lagos. } \\
\text { Tel: } 2600990\end{array}$ & 66 \\
\hline 29 & $\begin{array}{l}\text { LAGOS STATE DEVT. } \\
\text { \& PROPERTY CORP. } \\
\text { (LSDPC) }\end{array}$ & $\begin{array}{l}\text { Town Planning way, llupeju P.M.B } 21050 \text {, } \\
\text { lkeja. } 4972240\end{array}$ & 22,386 \\
\hline 30 & LEON SERVICES LTD. & $\begin{array}{l}\text { 4, Ladipo Oluwale Str. Off Adeniyi Jones, } \\
\text { Ikeja, Lagos. Tel: } 4939264\end{array}$ & 204 \\
\hline 31 & $\begin{array}{l}\text { LOFTY HEILS } \\
\text { ENTERPRISES LTD. }\end{array}$ & $\begin{array}{l}\text { No. 20, Bank Anthony Way, P.O. Box } 2596 \text {, } \\
\text { lkeja. Tel: } 4972689\end{array}$ & 98 \\
\hline 32 & $\begin{array}{l}\text { MAASK } \\
\text { DEVELOPMENT COY. } \\
\text { NIG LTD }\end{array}$ & 9/11, Association Avenue, Ilupeju, Lagos & 288 \\
\hline 33 & $\begin{array}{l}\text { MAGNA DEVT. \& } \\
\text { PROPERTIES LTD. }\end{array}$ & $\begin{array}{l}\text { 16, Boyle Street, Onikan Lagos P.O.Box } \\
54720 \text { Falomo Tel: } 2637460\end{array}$ & 76 \\
\hline 34 & $\begin{array}{l}\text { MATT OLSON INTER. } \\
\text { LTD }\end{array}$ & $\begin{array}{l}\text { 6, Adekoya Close, (Off Dehinde Street), Ifako- } \\
\text { Gbagada, Lagos. Tel: } 4706652\end{array}$ & 222 \\
\hline 35 & $\begin{array}{l}\text { NOSA OKUNGBOWA \& } \\
\text { CO. }\end{array}$ & $\begin{array}{l}\text { LAPAL House, 2nd Floor, 235, Igbosere road } \\
\text { Lagos, P.O.Box 76685, V/I. } 2632398\end{array}$ & 87 \\
\hline 36 & $\begin{array}{l}\text { ORA EGBUNIKE \& } \\
\text { ASS. }\end{array}$ & $\begin{array}{l}\text { Suite 4b, 6b, \& 7b, Entrance } 2 \text { first Floor, } \\
\text { Tafawa Balewa Square Complex, Race. } \\
\text { P.o.Box 51097, Ikoyi Tel: 01-2633399, } \\
\text { 2647919, 2647920. Fax 01-2634374, } \\
\text { 08033119291. }\end{array}$ & 229 \\
\hline 37 & $\begin{array}{l}\text { OWOLABI \& } \\
\text { PARTNERS }\end{array}$ & $\begin{array}{l}\text { 24, Obefemi Awolowo Way, Ikeja, Tel: } \\
4974694\end{array}$ & 125 \\
\hline
\end{tabular}




\begin{tabular}{|c|c|c|c|}
\hline 38 & PRIMAL TEK NIG. LTD & $\begin{array}{l}\text { Blk. D, Suite } 5 \text { lkeja Airport Shopping } \\
\text { Complex Ikeja, Along Motor Road. Tel: } \\
4976178,4719035\end{array}$ & 334 \\
\hline 39 & PRUDENT BANK PLC. & $\begin{array}{l}\text { Plot 708/709, Adeola Hopewell Str. V/I P.M.B. } \\
\text { 12764, Lagos Tel: } 2620161-3\end{array}$ & 323 \\
\hline 40 & PYRAMIDS & $\begin{array}{l}\text { 9, Chief Onitama Str. Off Adebola Str. } \\
\text { P.O.Box 3684, Surulere, Lagos Tel: }\end{array}$ & 434 \\
\hline 41 & $\begin{array}{l}\text { SAFETRUST SAVINGS } \\
\text { AND LOANS }\end{array}$ & 18, Keffi Street, P.O.Box 54408, Ikoyi & 105 \\
\hline 42 & SEARRAG NIG. LTD. & $\begin{array}{l}\text { 31/33, Ojo Igbede Road, Afribank Nig. Ltd. } \\
\text { Alaba int'l market Tel: } 7731449\end{array}$ & 253 \\
\hline 43 & $\begin{array}{l}\text { SEAVIEW } \\
\text { PROPERTIES LTD. }\end{array}$ & $\begin{array}{l}\text { Seaview Plaza, } 216 \text { Broad Str. Lagos Tel. } \\
\text { 2665414, 2665556, } 2664741\end{array}$ & 76 \\
\hline 44 & $\begin{array}{l}\text { SHELTER INITIATIVES } \\
\text { LTD }\end{array}$ & $\begin{array}{l}\text { St. Peter's House, } 8^{\text {th }} \text { Floor, Ajele Str. (Off } \\
\text { broad Str. Lagos P.O.Box Falomo. Tel; 263- } \\
\text { 5194, Fax } 2636445\end{array}$ & 112 \\
\hline 45 & $\begin{array}{l}\text { SKYVIEW ESTATE } \\
\text { LTD. }\end{array}$ & $\begin{array}{l}\text { 1, Ozumba Mbadiwe Avenue. P.O. Box } \\
\text { 73635, V/Island. } \\
\text { Tel; 2626963-4 }\end{array}$ & 457 \\
\hline 46 & $\begin{array}{l}\text { SPARKLIGHT } \\
\text { PROPERTY DEV. CO. } \\
\text { LTD }\end{array}$ & $\begin{array}{l}\text { Olatunji House (1st Floor) } 299 \text { lkorodu Rd. Idi- } \\
\text { Iroko Maryland, P.O.Box 516, Ikeja. Tel } \\
4972251\end{array}$ & 490 \\
\hline 47 & $\begin{array}{l}\text { STALLION } \\
\text { PROPERTIES \& DEV. } \\
\text { CO LTD }\end{array}$ & $\begin{array}{l}\text { 2, Ajose Adeogun Str. V/I Lagos. Tel. } \\
2621650,611823, \text { Fax; 234-1-261650 }\end{array}$ & 453 \\
\hline 48 & $\begin{array}{l}\text { WEMABOD ESTATES } \\
\text { LTD. }\end{array}$ & $\begin{array}{l}\text { Western House, } 5^{\text {th }} \text { Floor, Broad Street, } \\
\text { Lagos }\end{array}$ & 9,650 \\
\hline
\end{tabular}

Source: REDAN Secretariat, 2010 


\section{University Library}

\section{- M M N E R VA A gateway to Melbourne's research publications}

Minerva Access is the Institutional Repository of The University of Melbourne

Author/s:

Agunbiade, M;Rajabifard, A;Bennett, R

Title:

Modes of housing production in developing countries: the contemporary role of land, labour, and capital in Lagos, Nigeria

Date:

2013-06-01

Citation:

Agunbiade, M., Rajabifard, A. \& Bennett, R. (2013). Modes of housing production in developing countries: the contemporary role of land, labour, and capital in Lagos, Nigeria. JOURNAL OF HOUSING AND THE BUILT ENVIRONMENT, 28 (2), pp.363-379. https:// doi.org/10.1007/s10901-012-9303-8.

Publication Status:

In Press

Persistent Link:

http://hdl.handle.net/11343/32707 